\title{
Framework for the evaluation of credit policy changes
}

\author{
H.H. Phillips \\ School of Business Leadership, University of South Africa, Pretoria
}

For most business enterprises, credit sales and associated credit policies play a major role in over-all enterprise performance. The potential impact of planned or involuntary changes in one or more of the primary credit policy variables therefore warrants systematic evaluation. A number of possible approaches to the evaluation of credit changes are considered. 'Traditional' and the recently developed 'opportunity cost' approaches are found to be deficient. The former have a number of material shortcomings while the latter fail to cater adequately for the timing of cash flows associated with credit policy alternatives. Present and terminal value approaches are proposed as conceptually superior alternatives, since they offer consistent, versatile and lucid approaches to analysis of credit changes. Both avoid the problems surrounding other approaches, give full recognition to the timing of relevant cash flows, automatically embody the fundamental principles of incremental analysis and opportunity costs, and are easily applied and interpreted. Application of the suggested evaluation models is amply illustrated in the article.

S. Afr. J. Bus. Mgmt 1979, 10: 117-124

Vir die oorgrote meerderheid sake-ondernemings speel kredietverkope en gepaardgaande kredietbeleide 'n hoofrol in algehele ondernemingsprestasie. Die potensiële uitwerking van beplande of onvrywillige veranderinge in een of meer kredietbeleidsveranderlikes regverdig dus sistematiese ontleding. ' $n$ Aantal moontlike benaderinge tot die ontleding van kredietveranderinge word beskou. Die 'tradisionele' en meer resente 'geleentheidskoste' benaderinge het albei tekortkominge. Eersgenoemde het 'n aantal wesenlike tekortkominge terwyl laasgenoemde onvoldoende voorsiening maak vir die tydsberekening van kontantvloei verbonde aan kredietbeleidsalternatiewe. Huidige waarde en eindwaarde-metodes word voorgestel as konseptueelgesonde alternatiewe, aangesien hulle konsekwente, aanpasbare en duidelike benaderinge tot ontleding van kredietveranderinge bied. Beide metodes vermy die probleme onderliggend aan ander benaderinge, maak volle voorsiening vir die tydsberekening van kontantvloeie, lyf outomaties die fundamentele beginsels van inkrementele analise en geleentheidskoste in, en kan betreklik maklik toegepas en vertolk word. Toepassing van die voorgestelde ontledingsmodelle word breedvoerig in die artikel geïllustreer.

S.Afr. Tydskr. BedryfsI. 1979, 10: 117-124

H.H. Phillips

Professor, School of Business Leadership, University of South Africa,

P.O. Box 392, Pretoria 0001, South Africa

Received 22 June 1979
Credit sales today play a major role in the conduct of business for most companies. For the typical firm, the extension of trade credit entails a substantial investment in accounts receivable - an investment which needs to be effectively managed to safeguard and, where possible, enhance the performance and associated value of the firm.

The level of investment in accounts receivable and the ultimate profitability of credit sales are governed largely by a firm's credit policy. The four primary controllable credit policy variables are:

- credit standards (or standards for the extension of credit), which determine the number, calibre and buying limits of credit customers;

- discounts allowed for early payment;

- the credit period, or the average period of credit allowed by the firm; and

- collection policies, relating primarily to procedures for the collection of overdue accounts.

Individually and in concert, these policy variables influence a firm's performance through their impact on the total contribution margin, the level of fixed costs, the magnitude of the investment in accounts receivable, the amount of uncollectable sales (bad debts) and the timing of accounts receivable collections.

Most firms will, from time to time, need to assess the potential outcome of a contemplated or involuntary 'credit change' (a change in one or more of the primary policy variables), where a credit change could include:

- a change from an existing to a new credit policy;

- a change from cash to credit sales, or the converse;

- a decision to commence or terminate sales to credit card holders or members of co-operative buying societies (in such cases, commissions payable to, and periods to receipt of consolidated payments from, the relevant organizations are the equivalent of discounts and credit periods respectively);

- involuntary changes attributable to environmental circumstances, such as delayed payment of accounts during recessionary periods. 
There is therefore a need for a basic, general model to facilitate evaluation of credit changes. Increased sophistication, such as the recognition of uncertainty in the determination of input variables, could be incorporated in the model according to the needs and analytical capabilities of the individual enterprise.

\section{Current approaches}

In essence, the desirability of a credit change depends on the relative levels of incremental revenues and costs emanating from the change, where costs include variable and direct fixed costs of goods sold, the cost of incremental capital invested in accounts receivable, administration and collection expenses, and bad debt losses.

Most of the current financial management textbooks ${ }^{1,2.3}$ deal, in varying depth, with the evaluation of credit changes. However, the 'traditional approaches' adopted in such texts lack uniformity and are conceptually incorrect, primarily in the computation of the incremental investment in accounts receivable, where opportunity costs are only partially recognized. The major shortcomings of these traditional approaches were recently highlighted by a number of authors ${ }^{4.5 .6 .7}$ who attempted to resolve the issues by modifying and, in some instances, extending the traditional models. However, virtually all of the suggested models, although an improvement on the traditional approaches, also have a number of shortcomings which suggest continued misunderstanding in this area.

This article deals briefly with the major shortcomings of currently recommended evaluation models and seeks to clarify and resolve the issues by presenting two consistent, relatively straight forward approaches, one of which was partially covered in a recent article ${ }^{8}$, to the evaluation of credit changes. To simplify presentation, the analyses are on a pre-tax basis under conditions of certainty. Neither of these two simplifying assumptions detract from the fundamental validity of the analyses and findings.

Systematic integration of the primary areas of working capital management (cash, inventory and accounts receivable) into a firm's overall investment evaluation system is beyond the scope of this article, but is currently being developed at the UNISA School of Business Leadership and will be reported on at a later date.

In the ensuing discussions, existing and suggested approaches to the evaluation of credit changes are grouped into the following categories:

- Traditional approaches, being those methods which are adopted in a number of current, widely acknowledged textbooks

- Opportunity cost approaches, as presented in recent papers, which focus on modification of the traditional approaches

- Terminal and present value approaches, aimed at uniform, consistent evaluation.

\section{Traditional Approaches}

The traditional, textbook approaches characteristically base the incremental investment in accounts receivable, a key variable in the analysis, on the variable cost of sales. The following simple illustration, which avoids the complications of discount and bad debt movements, is ar- bitrarily taken, with minor adaptation, from Van Horne ${ }^{2, p 373-374}$ to exemplify the traditional approach:

Input data:

$\begin{array}{cc}\text { Existing } & \text { Proposed } \\ \text { policy } & \text { policy }\end{array}$

Annual sales

R2 $400000 \quad$ R3 000000

Annual turn-over of accounts receivable

12 times 6 times

Average collection period 30 days 60 days

Unit selling price of product R $10,00 \quad R 10,00$

Unit variable cost of product

R7,00 R7,00

Required annual rate of return on investment

$20 \%$

$20 \%$

Analysis of proposed credit change:

Profit on additional sales (30\% of R600 000) R180000

Existing level of accounts receivable R200 000

$\left(\frac{\text { Sales }}{\text { Receivables turnover }}=\frac{\text { R2 } 400000}{12}\right)$

Increased level of accounts receivable

R500 000 $\left(\frac{\mathrm{R} 3000000}{6}\right)$

Incremental accounts receivable

$\mathrm{R} 300000$

Incremental investment in accounts receivable $\mathrm{R} 210000$ (Incremental receivables $\times$ variable cost ratio $=\mathbf{R} 300000 \times 0,7)$

Required return on incremental investment

R42 000 $(20 \%$ of R210 000)

Excess return, favouring the credit change

R138000 (R180 000 - R42 000)

The fundamental weakness of this analysis lies in the use of variable cost, rather than the full selling price, as the basis for measuring the investment in existing accounts receivable for the additional 30-day credit period, thereby overlooking the opportunity cost of deferred receipt of the profit portion of sales (a 360-day year is assumed throughout for convenience). This point can be clarified by decomposing the $R 42000$ required return on investment into the following two components:

Required return on extended investment in existing receivables $(20 \%$ of $70 \%$ of $\mathrm{R} 200$ 000)

R28 000

Required return on investment in addi-

tional sales $\left(20 \%\right.$ of $70 \%$ of $\left.\frac{\text { R } 600000}{6}\right)$

$\mathrm{R} 14000$

$\mathrm{R} 42000$

The full R200 000 value of existing receivables would, however, have been collected after $\mathbf{3 0}$ days under the existing policy. This amount could then have been reinvested at, say, a $20 \%$ annual yield to produce additional revenue of $\mathrm{R} 40000$. The opportunity cost of deferred receipt of existing receivables is therefore $R 40000$ rather than the $R 28000$ reflected above. The R12000 difference represents the opportunity cost of deferred receipt of the profit embodied in accounts receivable $(20 \%$ of $30 \%$ of R200 $000=\mathrm{R} 12000)$. Adjusting for the $\mathrm{R} 12000$ error, the required and excess returns become R54 000 and R126 000, respectively. 
An alternative, possibly more lucid approach to revised analysis of the proposed credit change is the following:

Profit on additional sales (30\% of R600 000) R180 000

Financing cost of deferred collection of initial annual sales (Annual sales $\times$ required daily rate of return on investment $x$ additional credit period $=R 2400000$ $\times \frac{0,20}{360} \times 30$ days)

Financing cost of investment in additional sales

(Variable cost $\times$ required daily rate of return on investment $x$ full investment period $=\mathrm{R} 600000 \times 0,7 \times \frac{0,20}{360} \times 60$ days)

Potential net gain from credit change $\overline{\mathrm{R} 126000}$

where the R40 000 cost of deferred collection of initial annual sales comprises the following two components:

Financing cost of deferred recovery of the variable cost of initial sales

(R2 $400000 \times 0,7 \times \frac{0,2}{360} \times 30$ ) R28 000

Opportunity cost of deferred receipt of the profit on initial sales

(R2 $400000 \times 0,3 \times \frac{0,2}{360} \times 30$ )

$R 12000$

$\underline{\mathrm{R} 40000}$

The primary deficiency of the traditional approach, still prevalent in current textbooks, is therefore the failure to account for the opportunity cost associated with deferred receipt of profits. Additional problems would be encountered with the introduction of discounts and had debts, particularly when evaluating a change involving a reduced credit period. Such problems will be highlighted in the ensuing sections.

\section{Opportunity cost approaches}

Commencing with an article by $\mathrm{John} \mathrm{Oh}^{4}$, a spate of recent papers ${ }^{5,6,7}$ have focused on modification of the traditional approaches in order to formulate a general, versatile model which gives full recognition to opportunity cost principles. However, the series of corrections and extensions in these papers points to continued lack of agreement in this area.

John $\mathrm{Oh}^{4}$ was one of the first to highlight the deficiencies of the traditional approaches in the literature. However, his proposed model has a number of shortcomings, some of which were highlighted by Dyl ${ }^{6}$. Unfortunately, Dyl's treatment is incomplete in that it oversimplifies the issue by avoiding discounts and changes in bad debt losses attributable to customers who existed prior to the credit change and remained as customers after the change. As these two variables pose some of the major problems in credit analysis, Dyl's contribution, though useful, is rather limited. Walia's attempt ${ }^{s}$ was also partially unsuccessful.

Celec and Icerman' subsequently sought to resolve the issue by developing 'a general model for the analysis of credit changes that is complete in its treatment of all relevant variables and is consistent with the basic principles of incremental analysis and opportunity cost'. Although this paper presents probably the most successful modification of the traditional approaches, it still embodies the following deficiencies, which are also common to most of the other proposals:

- The opportunity cost associated with deferred collection of accounts receivable is overstated in that the cost of deferred recovery of bad debt losses on original sales is not correctly accounted for

- The model, if applied in cases involving credit period reductions (expedited receipt of accounts receivable), would use compounding factors in situations where discounting is the appropriate computational technique

- As the impacts of the various changes are not all measured at the same time-point, the time value of money is not fully accounted for

- A number of potentially significant variables are excluded from the analysis.

Further modification would therefore be required to arrive at a consistent, flexible, conceptually sound evaluation model.

Space does not permit a detailed review of each of the above papers. Interested readers are referred to those papers, which generally incorporate brief reviews of previous proposals. Each proposal has deficiencies, the removal of which would ultimately lead to a model which measures all of the incremental costs and revenues at a common time-point, thereby accounting fully for the time value of money. Two approaches which would meet the latter criterion are presented in the next section.

Before moving to the next section, a common misconception regarding the timing of bad debt losses should be highlighted. A number of authors explicitly or implicitly assume that bad debt losses are incurred at the time of sale. This might be valid in an accounting sense, but from a cash flow viewpoint - the appropriate viewpoint in credit analysis - such an assumption is incorrect. Any investment in the cost of uncollectable sales can be recovered only out of profits on collectable sales. Bad debt losses therefore act as a reduction of such profits. But profits on collectable sales are realized only on collection of the associated accounts receivable. In cash flow terms, it is therefore only at this point in time that bad debt losses are effectively incurred. In effect, the assumption that bad debt losses are incurred at the time of sale amounts to a rejection of the time value of money principle. Unlike the traditional formulations, the present and terminal value approaches to credit analysis automatically recognize the correct timing of bad debt losses.

\section{Present and terminal value approaches}

Present value (PV) and terminal value (TV) formulations appear to offer the most consistent, versatile and lucid approaches to analysis of credit changes. Both avoid the problems surrounding other approaches, give full recognition to the time value of money principle, automatically embody the basic principles of incremental analysis and opportunity costs and, importantly, are easily applied and interpreted.

Two cases will be used to illustrate the PV and TV approaches. Being 'reverse' cases (each is the reverse of the 
other), reconciliation of the individual results will serve to verify the accuracy and consistency of the models. The cases were designed to test the validity of the models in relatively complex situations and are not purported to represent typical practical situations.

Case A: Credit period reduction

\begin{tabular}{|c|c|c|}
\hline & $\begin{array}{l}\text { Existing } \\
\text { policy }\end{array}$ & $\begin{array}{l}\text { Proposed } \\
\text { policy }\end{array}$ \\
\hline Gross annual sales & R1 000000 & R1 050000 \\
\hline Variable costs ( $\%$ of sales) & $60 \%$ & $60 \%$ \\
\hline Direct fixed costs & R 100000 & R 105000 \\
\hline Bad debts ( $\%$ of gross sales) & $3 \%$ & $2 \%$ \\
\hline $\begin{array}{l}\text { Cash discount ( } \% \text { of dis- } \\
\text { count sales) }\end{array}$ & $1 \%$ & $2 \%$ \\
\hline Discount period & 15 days & 10 days \\
\hline Net-payment period* & 40 days & 30 days \\
\hline $\begin{array}{l}\text { Customers taking discount } \\
\text { ( } \% \text { of net sales) }\end{array}$ & $40 \%$ & $50 \%$ \\
\hline $\begin{array}{l}\text { Customers taking net term } \\
\text { (\% of net sales) }\end{array}$ & $60 \%$ & $50 \%$ \\
\hline $\begin{array}{l}\text { Minimum required rate of } \\
\text { return on investment (an- } \\
\text { nual; pre-tax) }\end{array}$ & $20 \%$ & $20 \%$ \\
\hline
\end{tabular}

\section{Case B: Credit period extension}

Reverse of Case A. The existing and proposed policies in Case $\mathrm{A}$ become the proposed and existing policies, respectively, in Case B.

Absolute changes which would result from the credit policy change are set out in some detail in the Appendix to facilitate understanding of the ensuing case analyses.

The PV and TV approaches involve adjustment of all cash receipts and outlays to a common point in time in order to allow fully and consistently for the time value of money. Adopting the PV option, a convenient time-point would be the start of the credit period (date of sale of the goods) although the use of any other time-points, such as the lower (existing proposed policy) average accounts receivable collection point, would yield identical policy decisions. For a TV approach, the final day of the longer net payment period would be most convenient to ensure compounding, rather than a mix of compounding and discounting, of all variables. (The terms 'compounding' and 'discounting' are used for both simple and compound interest formulations.) Either simple or compound interest formulations may be used in both the PV and TV approaches.

A universal, fundamental formula for use under the PV and TV approaches is:

$$
\begin{aligned}
\Delta P= & {\left[S_{N}\left(1-B_{N}\right)\left(P_{N}\right)\left(1-D_{N}\right)\right]_{P V}^{T V}(\mathrm{i}, A) } \\
& +\left[S_{N}\left(1-B_{N}\right)\left(1-P_{N}\right)\right]_{P V}^{T V}(\mathrm{i}, \mathrm{B}) \\
& -\left[V\left(S_{N}-S_{o}\right)\right]_{P V}^{T V}(\mathrm{i}, \mathrm{C})
\end{aligned}
$$

$$
\begin{aligned}
& -\left[F_{N}-F_{o}\right]_{P V}^{T V}(i, C) \\
& -\left[S_{o}\left(1-B_{o}\right)\left(P_{o}\right)\left(1-D_{o}\right)\right]_{P V}^{T V}(i, D) \\
& -\left[S_{o}\left(1-B_{o}\right)\left(1-P_{o}\right)\right]_{P V}^{C V}(i, E)
\end{aligned}
$$

where

$\Delta \mathrm{P} \quad=$ Net gain/loss resulting from a credit change

$S_{N}$ and $S_{o}=$ Gross sales under proposed and existing policies

$\mathbf{B}_{N}$ and $\mathbf{B}_{o}=$ Bad debt ratios under proposed and existing policies

$P_{N}$ and $P_{0}=$ Customers taking discounts under proposed and existing policies

$\mathrm{D}_{N}$ and $\mathrm{D}_{o}=$ Discount rates under proposed and existing policies

$F_{N}$ and $F_{o}=$ Fixed costs under proposed and existing policies

$\mathrm{V}=$ Variable costs as a ratio of sales

TV $(\mathrm{i}, \mathrm{A}-\mathrm{E})=$ Terminal value factor for the period from the time of the relevant cash flow to the final day of the longer net payment period

PV $(\mathrm{i}, \mathrm{A}-\mathrm{E})=$ Present value factor for the period from the time of the relevant cash flow to the time-point chosen for comparison.

The six components of the formula represent, in the order in which they appear in the formula:

- Net sales, under the proposed policy, to discount customers;

- Collectable sales, under the proposed policy, to netpayment customers;

- Incremental variable costs;

- Incremental fixed costs;

- Net sales, under the existing policy, to discount customers;

- Collectable sales, under the existing policy, to netpayment customers.

Compounding and discounting factors for simple and compound interest applications are derived from the following:

Compounding: Simple interest $1+\left(\frac{i}{360}\right) \cdot N$

$$
\text { Compound interest }\left(1+\frac{i}{360}\right)^{N}
$$

Discounting: Simple interest

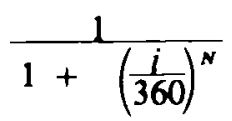

Compound interest

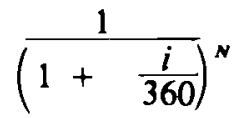

where

$i$ is the required annual rate of return (20\% in the cases) $N$ is the relevant period (days, in the present context).

Applying a TV, simple interest version of the evaluation model to Case $\mathbf{A}$, the net result of the proposed change is: 


$$
\begin{aligned}
\Delta \mathrm{P}= & {[1050000(0,98)(0,5)(0,98)] \mathrm{TV}(\mathrm{i}, \mathrm{A}) } \\
& +[1050000(0,98)(0,5)] \mathrm{TV}(\mathrm{i}, \mathrm{B}) \\
& -[0,6(50000)] \mathrm{TV}(\mathrm{i}, \mathrm{C})-[5000] \mathrm{TV}(\mathrm{i}, \mathrm{C}) \\
& -[1000000(0,97)(0,4)(0,99)] \mathrm{TV}(\mathrm{i}, \mathrm{D}) \\
& -[1000000(0,97)(0,6)] \mathrm{TV}(\mathrm{i}, \mathrm{E}) \\
= & 504210\left[1+\left(\frac{0,20}{360}\right) \cdot 30\right] \\
& +514500\left[1+\left(\frac{0,20}{360}\right) \cdot 10\right] \\
& -30000\left[1+\left(\frac{0,20}{360}\right) \cdot 40\right] \\
& -5000\left[1+\left(\frac{0,20}{360}\right) \cdot 40\right] \\
& -384120\left[1+\left(\frac{0,20}{360}\right) \cdot 25\right] \\
& -582000\left[1+\left(\frac{0,20}{360}\right) \cdot 0\right]
\end{aligned}
$$

= R22 739 net benefit from the policy change.

Application of the same version of the model to Case B yields a R22 739 net loss, thus evidencing the consistency of the model.

Applying a PV, simple interest version of the model to Case $A$ results in:

$$
\begin{aligned}
\Delta P & =[1050000(0,98)(0,5)(0,98)]\left[1+\left(\frac{0,20}{360}\right) \cdot 10\right]^{-1} \\
& +[1050000(0,98)(0,5)]\left[1+\left(\frac{0,20}{360}\right) \cdot 30\right]^{-1} \\
& -[0,6(50000)]\left[1+\left(\frac{0,20}{360}\right) \cdot 0\right]^{-1} \\
& -5000\left[1+\left(\frac{0,20}{360}\right) \cdot 0\right]^{-1} \\
& -[1000000(0,97)(0,4)(0,99)]\left[1+\left(\frac{0,20}{360}\right) \cdot 15\right]^{-1} \\
& -[1000000(0,97)(0,6)]\left[1+\left(\frac{0,20}{360}\right) \cdot 40\right]^{-1}
\end{aligned}
$$

$=\mathrm{R} 22196$ net benefit from the credit change.

Application of this PV version of Case B yields a R22 196 loss. Again the results are consistent. The R22 739 terminal value and R22 196 present value are also easily reconciled to validate the results.

Applying compound interest versions of the model produces the following results:

Terminal value: Case A - R22 770 net gain
B - R22 770 net loss

Present value: Case A - R22 270 net gain

$$
\text { B - R22 } 270 \text { net loss. }
$$

These two values are easily reconciled. R22 270 compounded for 40 days to the final day of the longer net

payment period $=\mathbf{R} 22270\left(1+\frac{0,20}{360}\right)^{40}=\mathbf{R} 22770$.
Clearly the gain in Case $A$ should always equal the loss in Case B. If this were not the case, a firm could build or lose wealth by merely oscillating between two credit policies.

An important point to bear in mind is that the above illustrations assumed annual compounding for the simple interest approach and daily compounding for the compound interest approach. In practice, the appropriate compound/discount rate must be established. If, for example, bi-annual compounding is applicable, the effective annual equivalent of a $20 \%$ nominal annual rate will be

$\left(1+\frac{0,20}{2}\right)^{2}-1=21 \%$. If this is the case, then

- the $21 \%$ effective annual rate should be used in the simple interest applications, and

- a daily rate of $(1+0,21)^{\frac{1}{360}}-1=0,053 \%$ should replace the component $\frac{0,20}{360}$ in the compound interest applications (a rate of $\frac{0,20}{360}$ per day compounded daily is equivalent to an effective annual rate of $22,13 \%$.)

\section{Extended benefits and wealth maximization}

The above PV and TV models measure the net impact of a credit change at a selected time-point for only one operating cycle (a single year in the illustrations). Assuming a 360-day year and that production and sales are evenly distributed over the year, the points in time at which the benefits/losses are measured in the above analyses are 180 and 220 days removed from the policy implementation date under the PV and TV approaches, respectively. The results of such analyses are fully valid as criteria for a choice between credit policy alternatives. However, they do not measure the value of the total potential benefits at the implementation date in accordance with generally accepted wealth maximization criteria. To achieve this, the following additional steps are required:

- Recognition of the full benefits/losses for the period over which the firm expects the benefits/losses to extend, by treating the result of the single-period evaluation as an annuity which will accrue annually over the extended period

- Conversion of the value established in step 1 above to its equivalent value at the implementation date, thereby establishing the net present value of the total benefits or losses.

Reverting to the compound interest version of the PV approach to Case $A$ and assuming that the benefits flowing from the proposed policy are expected to continue for a 10-year period, the present value of the total benefits would, assuming daily compounding, be

$$
\begin{aligned}
& \text { R22 } 270\left[1-(1,2213)^{-10}\right](0,2213)^{-1} \\
& {\left[1+\frac{0,20}{360}\right]^{-120}=\operatorname{R} 78725}
\end{aligned}
$$


measured at implementation date. Alternatively, appropriate present value factors can be applied to each component of the above valuation model. The other versions of the model could be extended in a similar manner.

\section{Average collection periods}

Average accounts receivable collection periods (ACPs) are commonly used in credit policy evaluations. Equation 1 can readily be adapted to the use of ACPs. Taking the present value version as an example, the model would become:

$$
\begin{aligned}
\Delta P= & S_{N}\left(1-B_{N}\right)\left[1-\left(P_{N}\right)\left(D_{N}\right)\right] P V(i, X) \\
& -V\left(S_{N}-S_{o}\right) P V(i, C)-\left(F_{N}-F_{o}\right) P V(i, C) \\
& -S_{0}\left(1-B_{o}\right)\left[1-\left(P_{o}\right)\left(D_{o}\right)\right] P V(i, Z)
\end{aligned}
$$

where $\mathrm{X}$ and $\mathrm{Z}$ represent the $\mathrm{ACPs}$ under the proposed and existing policies, respectively.

The following formula can be used to calculate the relevant ACPs:

$C_{A}=\frac{(P)(1-D)\left(C_{D}\right)+(1-P)\left(C_{F}\right)}{P(1-D)+(1-P)}$

where

$\mathbf{P} \quad=$ Portion of customers taking discounts

D $=$ Discount rate

$C_{D}=$ Discount period

$\mathrm{C}_{\mathrm{F}}=$ Net payment period

$\mathrm{C}_{\mathrm{A}}=$ Average collection period

Applying Eq. 3 to Case A, the ACPs under the proposed and existing policies are 20,10 days and 30,06 days respectively. Applying a simple interest version of Eq. 2 results in:

$$
\begin{aligned}
\Delta P= & 1050000(0,98)[1-(0,5)(0,02)] P V(i, X) \\
& -0,6(50000) P V(i, C)-(5000) P V(i, C) \\
& -1000000(0,97)[1-(0,4)(0,01)] P V(i, Z) \\
= & 1018710\left[1+\left(\frac{0,2}{360}\right)(20,10)\right]^{-1} \\
& -35000\left[1+\left(\frac{0,2}{360}\right) \cdot(0)\right]^{-1} \\
& -966120\left[1+\left(\frac{0,2}{360}\right)(30,06)\right]^{-1}
\end{aligned}
$$

$=\mathbf{R} 22208$ net benefit

The difference of R12 (= R22 208 - R22 196) between this and the previous result stems from the use of approximate ACPs derived from Eq. 3. Accurate ACPs can be calculated by equating the present value of total sales with the sum of the present values of the two components of total sales. Adopting this approach, the ACP under the proposed policy is derived from the following equation:

$$
\begin{aligned}
& 1018710\left[1+\left(\frac{0,2}{360}\right) \cdot \mathrm{X}\right]^{-1} \\
& =504210\left[1+\left(\frac{0,2}{360}\right) \cdot 10\right]^{-1} \\
& \quad+514500\left[1+\left(\frac{0,2}{360}\right) \cdot 30\right]^{-1}
\end{aligned}
$$

Solving for ' $X$ ' yields an accurate ACP of 20,05 days. Similarly the ACP under the existing policy is 29,98 days. Use of these ACPs in Eq. 2 will yield a R22 196 net benefit. Derivation of accurate ACPs for use in compound interest versions of Eq. 1 would proceed along the same lines but is more complex and will not be dealt with here.

Although Eq. 3 does not produce completely accurate ACPs, the above results show that the distortions are insignificant and unlikely to influence a policy decision. Equation 3 should therefore suffice for practical purposes.

\section{Supplier credit}

The minimum required rate of return used in the analysis (20\% in the present examples) would normally be the firm's weighted-average cost of capital. If supplier credit (credit furnished bythe firm's suppliers) is not embodied in the calculated cost of capital, Eq. 1 must be adapted to recognize the average period of credit allowed by suppliers, which effectively defers the cash outflows associated with the cost of sales. To cater for supplier credit, the component $\left(\mathrm{V}_{s}\left(\mathrm{~S}_{\mathrm{N}}-\mathrm{S}_{\mathrm{O}}\right)\right)_{\mathrm{PV}}^{\mathrm{TV}}\left(\mathrm{i}, \mathrm{C}_{\mathrm{s}}\right)$, where $\mathrm{V}_{\mathrm{s}}$ is the variable cost ratio adjusted to take account of the proportion of variable costs which are financed by suppliers and $\mathrm{C}_{5}$ is the average period of supplier credit, could be included in Eq. 1.

\section{Cost holding-period}

Equation 1 assumes that the cash flows associated with the costs of additional or forfeited sales occur on the date of sale. This is normally not the case. Most firms will, for example, carry inventories of raw materials, work-inprocess and finished goods for varying periods prior to sale. To cater for the 'holding period' of costs of sales, the component $\left(V_{H}\left(S_{N}-S_{O}\right)\right) T V\left(i, C_{H}\right)$, where $V_{H}$ is the variable cost ratio adjusted to take account of the proportion of variable costs which are 'held in stock' and $\mathrm{C}_{\mathrm{H}}$ is the average period for which costs are 'held' between the date of payment of suppliers and the date of sale, could be included in Eq. 1. This component would employ a compounding factor in all versions of the evaluation model.

\section{Alternative problem statement}

Input data for Cases A and B specified bad debts as percentages of gross sales and discount and net-term sales as percentages of net collectable sales. Alternatively, discount and net-term sales could be stated as percentages of gross sales with bad debts stated as percentages of nondiscount sales. Reverting to Case A, the three affected variables would be re-stated as follows: 


$\begin{array}{cc}\text { Existing } & \text { Proposed } \\ \text { policy }(\%) & \text { policy }(\%)\end{array}$

Discount sales ( $\%$ of gross sales)

Non-discount sales $(\%$ of gross sales)

Bad debts (\% of nondiscount sales)

$$
4,90
$$

Should the input data be stated in this form, $B_{N}$ and $B_{o}$ in the first and fifth components of Eq. 1 would be reduced to zero. Again the terminal and present value approaches would automatically recognise the correct timing of cash inflows and outlays.

Use of the above modified data in a terminal value, simple interest application of Eq. 1 to Case A would yield:

$$
\begin{aligned}
\Delta \mathrm{P}= & {[1050000(1)(0,49)(0,98)] \mathrm{TV}(\mathrm{i}, \mathrm{A}) } \\
& +[1050000(0,96))(0,51)] \mathrm{TV}(\mathrm{i}, \mathrm{B}) \\
& -[0,6(50000)] \mathrm{TV}(\mathrm{i}, \mathrm{C})-[5000] \mathrm{TV}(\mathrm{i}, \mathrm{C}) \\
& -[1000000(1)(0,39)(0,99)] \mathrm{TV}(\mathrm{i}, \mathrm{D}) \\
& +[1000000(0,95)(0,61)] \mathrm{TV}(\mathrm{i}, \mathrm{E})
\end{aligned}
$$

$=\mathrm{R} 22739$ net benefit from the policy change, which is identical to the result obtained with the original input data.

Equation 1 is therefore valid irrespective of the data format.

Use of average collection periods and the above alternative format would necessitate minor modifications of Eqs. 2 and 3. However, data extracted in the alternative format can easily be converted to the original format (the reverse of the above change from the original format) for use in Eqs. 2 and 3.

Data in any other format could similarly be used, possibly with appropriate modification, in Eqs. 1-3.

\section{Comparison of models}

The following four versions of the evaluation model represented by Eq. 1 were reviewed:

- Terminal value employing simple interest

- Terminal value employing compound interest

- Present value employing simple interest

- Present value employing compound interest.

Considering first the choice between simple and compound interest formulations, the compound interest formulation is superior in that it not only provides a basis for the choice between credit policy alternatives but is also best suited to measurement, at the implementation date, of the value of benefits extending over a period of more than one year. In addition, compound interest factors are readily adpated to take account of the frequency with which interest is compounded in any particular situation.
Turning to the choice between the present and terminal value approaches, there is no clear advantage to either method. Both offer equally valid selection criteria and are suited to the calculation of the present value of total benefits in accordance with the wealth maximization principle. However, relative calculating ease might give the present value approach marginal superiority.

Finally, comparison of the expanded and ACP models (Eqs. 1 \& 2) favours the expanded model, which provides greater accuracy and flexibility. Accurate results with the present value, compound interest version of the ACP model entail complex calculations to determine the average collection period. Although acceptable average collectable periods can be derived from Eq. 3, the expanded model yields more accurate results with relative ease.

In essence, then, the present value approach, using the expanded model and a compound interest formulation, appears to provide the best approach to evaluation of credit policy changes.

\section{Conclusion}

This article dealt with various approaches to the evaluation of planned or involuntary credit policy changes. Both the 'traditional' and subsequent 'opportunity cost' approaches were found to be deficient. Terminal and present value models, using either simple or compound interest formulations, were shown to be consistent, conceptually superior alternatives. A present value approach, using a compound interest formulation, was ultimately selected as the most convenient framework for the evaluation of credit changes.

The author does not profess to have resolved all of the problems underlying credit evaluation. Indeed, a number of issues, such as the determination of appropriate input data, represent fertile fields of research in their own right. Hopefully, however, this article will clarify some of the major issues and stimulate interest and further development in this highly significant facet of enterprise management.

\section{Acknowledgement}

The author is grateful to Prefessor D W Goedhuys, of the University of the Witwatersrand Graduate School of Business Administration for his valuable comments on the initial draft of this article.

\section{References}

1 WESTON, J.F. \& BRIGHAM, E.F. Managerial finance. 6th Ed. The Dryden Press: Hinsdale, llinois. 1978.

2 VAN HORNE, J.C. Financial management and policy. 4th Ed. Prentice-Hall Inc.:Englewood Cliffs, New Jersey. 1977.

3 JEAN, W.H. Finance. The Dryden Press: Hinsdale, Illinois. 1973.

$4 \mathrm{OH}, \mathrm{J} . \mathrm{S}$. Opportunity cost in the evaluation of investment in account receivable. Finan. Mgmt 5: 32.1976.

5 WALIA, T.S. Explicit and implicit cost of changes in the level of account receivable and the credit policy decision of the firm. Finan. Mgmt 6: 75. 1977.

6 DYL, E.A. Another look at the evaluation of investment in accounts receivable. 1977. Finan. Mgmt 6: 67.

7 CELEC, S.E. \& ICERMAN, J.D. A comprehensive model for accounts receivable management. Unpublished Working Paper, Florida State University. 1978.

8 KIM, Y.H. \& ATKINS, J.C. Evaluating investments in acounts receivable: A wealth maximizing framework. 1978. J. Finan. 33(2): 403. 
Appendix: Absolute changes resulting from the credit-change

\begin{tabular}{ccccc} 
Existing & $\begin{array}{c}\text { Amended } \\
\text { existing }\end{array}$ & XS & $\begin{array}{c}\text { Proposed } \\
\text { policy }\end{array}$ & Change \\
\hline $\begin{array}{c}\text { Original } \\
\text { sales } \\
\begin{array}{c}\text { Original } \\
\text { policy }\end{array}\end{array}$ & $\begin{array}{c}\text { Original } \\
\text { sales } \\
\text { Proposed } \\
\text { policy }\end{array}$ & $\begin{array}{c}\text { Incremental } \\
\text { sales } \\
\text { Proposed } \\
\text { policy }\end{array}$ & $\begin{array}{c}\text { Amended } \\
\text { sales } \\
\text { Proposed } \\
\text { policy }\end{array}$ & $\begin{array}{c}\text { Existing } \\
\mathbf{v} \\
\text { Proposed } \\
\text { policies }\end{array}$ \\
\hline $\mathbf{R}$ & $\mathbf{R}$ & $\mathbf{R}$ & $\mathbf{R}$ & $\mathbf{R}$ \\
$(1)$ & $(2)$ & $(3)$ & $(4=2+3)$ & $(4-1)$
\end{tabular}

\section{CASE A}

Gross sales

1000000

1000000

50000

1050000

50000

Deduct: Bad debts

30000

20000

1000

21000

9000

Collectable sales

970000

Discount sales

Deduct: Discounts

\begin{tabular}{rrrrr}
\hline 388000 & 490000 & 24500 & 514500 & 126500 \\
3880 & 9800 & 490 & 10290 & 6410 \\
\hline 384120 & 480200 & 24010 & 504210 & 120090 \\
582000 & 490000 & 24500 & 514500 & $(67500)$ \\
\hline
\end{tabular}

Net discount sales

Net-payment sales

Net Collectable Sales

(a)

966120

970200

48510

1018710

52590

Cost of sales:

Variable costs

Direct fixed costs

600000

600000

30000

630000

30000

100000

100000

5000

105000

5000

Total costs of sales

(b) 700000

700000

35000

735000

35000

Net earnings

$(a-b)$

266120

270200

13510

283710

17590

\section{CASE B}

Net earnings 